Dr. Marghany Mahmoud Marghany

\title{
Interlanguage pragmatics of Egyptian EFL tertiary students: A sociopragmatic and TEFL perspective
}

Dr. Marghany Mahmoud Marghany Higher Institute for Specific Studies, Giza

\begin{abstract}
The study examines the refusal and acceptance strategies of invitation adopted by two different groups of Egyptian EFL tertiary students, majoring in English and ESP. This examination was conducted in terms of participants' L1 culture including social distance and social power. Thirty Egyptian EFL tertiary students participated in the study. They were divided into two groups with fifteen students each. Data were collected using a 12-item discourse completion task (DCT) questionnaire. Data were analyzed using descriptive statistics like frequencies, mean scores and percentages. One way analysis of variance (ANOVA) was conducted as well to judge statistical significance between contextual variables and categories of refusal and acceptance strategies. Findings indicate that Egyptian EFL learners vary in adopting acceptance strategies, however they tend to use similar strategies for refusing invitations. The study emphasizes the needs of teaching pragmatic behavior to Egyptian EFL tertiary students. Social contextual variables are found to have statistically significant influence on the selection of refusal and acceptance strategies adopted by Egyptian EFL students.
\end{abstract}

Keywords: interlanguage pragmatics, sociopragmatic competence, acceptance and refusal strategies of invitation, Egyptian EFL learners, FL pragmatic instructions.

\section{Background}

Barron (2003), Schauer (2004) and Bardovi-Harlig (2010) defined pragmatics as an action of communication within the parameters of social context. Interlanguage pragmatics is that branch of pragmatics which is mainly concerned with how L2 learners use the acquired knowledge of pragmatics. The realization of the speech act of invitation as performed by native speakers of English has been investigated in different cultures and languages as indicated in the literature review section. The different backgrounds of people who speak the same language may lead to misunderstanding and miscommunication. Thus, it is necessary to investigate into sociopragmatic transfer of EFL learners which means copying L1 cultural knowledge when performing an L2 speech act. In addition, Kapser and Rose (2001) Kasper (2002) and clarified that L2 pragmatic competence is intricately entwined with the Communicate Language Teaching (CLT). Success in English language communication largely depends on developing the linguistic competences at the syntactic, morphological, phonological and lexical levels. However, FL instructors are aware that EFL learners who can produce grammatically and phonologically correct utterance may fail due to their undeveloped pragmatic competence. The term "pragmatic competence" refers to the extent EFL learners can manage to interpret and express certain 
communicative functions in certain communicative contexts. It was necessary, therefore, to examine how Egyptian EFL learners can refuse and accept invitations in light of the Arabic culture and to address the element of teaching pragmatics to Egyptian EFL learners.

\section{Statement of the problem}

The present study examines the refusal and acceptance strategies of invitation adopted by two different groups of Egyptian EFL tertiary students majoring in English and ESP. This examination was conducted in terms of participants' L1 culture including social distance and social power (which are sometimes called as formality). The study also draws implications for the TEFL process in teaching different refusal and acceptance strategies to the speech act of inviting.

\section{Study Questions}

The study attempts to answer the following questions:

1. How do Egyptian EFL tertiary students vary in their refusal and acceptance of invitation according to their field of study?

2. Do their refusal and acceptance of invitation vary in terms of the social distance?

3. How do refusal and acceptance of invitation vary among Egyptian EFL tertiary students according to different levels of social power?

4. What are the teaching implications that can be drawn for improving foreign language teaching?

\section{Study Objectives}

The present study aims to explain the difference between Englishmajor Egyptian EFL learners and ESP Egyptian ones in adopting refusal and acceptance strategies. It also aims to clarify how social contextual variables can significantly influence the adoption of refusal and acceptance strategies. The study aims to draw implications as well for the necessity of teaching pragmatics to Egyptian EFL learners.

\section{Significance of the Study}

The present study is generally significant as it enriches the literature of the interlanguage pragmatic of Arab EFL learners. It has a particular significance as it gives insight to the FL instructors at the Higher Institute for Specific Studies to devise culturally-based activities in order to help develop the pragmatic competence of their Egyptian EFL students.

\section{Limitations of the study}

Findings of the present study are limited to the teaching of pragmatic competence through the core courses of conversation and the ESP courses at the Department of Languages and Translation on the one 
hand and the Department of Tourism on the other at the Higher Institute for Specific Studies.

\section{Literature review}

Felix-Brasdefer (2003) Examined how the native speakers of Spanish apply politeness in refusing an invitation in comparison to American speakers of English who were advanced learners of Spanish. He collected data based on role plays from 30 participants divided into three groups. Findings indicated that social factors including social relation and the situation were crucial to the adoption of refusal direct strategies adopted by the participants. The advanced American learners of the Spanish language indicated positive and negative types of interlanguage transfer while declining invitations in the Spanish language. This revealed that participants were not familiar with the cultural values and norms of the target language and lacked the Spanish sociopragmatic competence which qualifies them to realize the Spanish-native speakerlike strategies when refusing invitations.

In a similar study, Rakowicz (2009) investigated how Polish speakers of English deal with vague ways of L2 invitation. Rakowicz analysed participants' responses to the way they do when speaking Polish and to the way American speakers of English adopt when responding to invitation. Rakowicz collected data from 56 participants divided into two groups. Whereas one group comprised 26 Polish speakers of English, the other group included 30 Americans. Data collected based on an open DCT consisting of six various situations on invitation. Findings indicated that Polish speakers of English tended to apply the Polish strategies when responding to vague invitation. Rakowicz emphasized that Polish interlanguage negative transfer impedes their realization of American-like invitation strategies. Similar to Rakowicz' study, Wang (2003) reported similar results when compared the invitation-declining strategies of both Chinese EFL learners and American speakers of English. The Chinese cultural-based responses to the English invitation scenarios showed significant Chinese interlanguage transfer into the Chinese EFL learners in a violation of the English L2 pragmatic norms spread among the American speakers of English.

Salmani-Nodoushan (2006) examined the strategies Persians used to apply in offering two kinds of invitations: unreal invitations and serious invitations. The study differentiated between these two types according to the features proposed by Clark and Isaac' study in 1990. Salmani-Nodoushan (2006, p.905) named these features as "pretense, mutual recognition, collusion, ambivalence, and off-record purpose".

Suzuki (2009) explained the pragmatic strategies which the American native speakers of English used politely when expressing the 
speech act of invitation. This study is, indeed, relevant to the fourth aim of the current study as it explains the indirect strategies which Americans adopt in refusing or accepting invitations. Such strategies provide a teaching model which FL instructors can use in teaching the pragmatic behavior to their Egyptian EFL learners. Suzuki collected data from American undergraduates through two different instruments, namely DCT and role plays. The linguistic analysis was carried out on the basis of lexis, grammar and discourse. This analytical approach differs from that adopted in the present study which is mainly based on the cultural values of the target language community. Suzuki's findings provided a corpus of materials that can be natural and useful for use through the English language teaching to non-native speakers of English in order to train them producing the speech act of inviting. Suzuki determined the polite forms of inviting adopted by the Americans. These forms include declarative, interrogative and conditional + want/ like/ would, etc.

In addition, several interlaguage studies were conducted on Arab EFL learners to indicate the impact of Arabic social and cultural norms reflected in their pragmatic output. Al-Issa (2003) indicated the social and cultural values of Jordanian EFL learners reflected in their L2 English pragmatic performance. Al-Issa explained that according to the Arabs' cultures, Arabs used to exaggerate in praising their interlocutors as a means of pleasing them, strengthening ties among friends or even get money rewards for rendering services among strangers. Therefore, Jordanian EFL learners, tended to apply their culturally rooted norms by using elaborated sentences to justify their refusal and to avoid being misunderstood by their interlocutors. On the other hand, English native speakers prefer to use short semantic formulae to express their refusal.

Al-Eryani (2007) compared the Yemeni EFL learners' pragmatic performance to that of American native speakers of English. Findings indicated high level of interpragmatic transfer from the Arabic language into the Yemeni EFL learners performance in English pragmatics marked with the use of Arabic-based semantic patterns into English. Consequently, Yemeni EFL learners differed in their perception of the sequential order from the American native speakers of English in order to express refusal. The pragmalinguistic negative transfer was evident in the use of Yemeni EFL learners of the Arabic-based syntactic formula, which consists of 'can't' plus regret in order to express refusal. However, American native speaker usually tended to express their refusal by using the syntactic formula of 'no' plus regret. The Yemeni adopted formula of refusal was evidently adopted from their mother tongue striking an example of the negative interlanguage pragmatics. According to AlEryani social distance played as well a main role in determining the 


\section{Dr. Marghany Mahmoud Marghany}

refusal strategies adopted by the Yemeni EFL learners. They are likely to use direct refusal strategy to interlocutors of lower social class status. On the contrary, American native speakers of English do not usually prefer to use direct refusal strategies. Rather, they use excuses and justifications as ways of indirect refusal strategies. Similarly, Al-Khatib (2006) proved the influence of Arabic culture and social values on the Jordanian EFL learners of English in adopting invitation strategies.

Hamoud (2014) discussed the refusal strategies which Saudi EFL learners chose to use in a response to suggestion, invitation and offer. The study was considered as a pragmalinguistic examination of such refusal strategies in the perspectives of social factors that could determine variation in adopting the refusal strategies on the one hand. On the other hand, Hamouda examined as well the impact of pragmatic instruction on developing the ability of Saudi EFL to use the speech act of refusal. The study also sought identifying the views of Saudi EFL learners regarding the use of explicit instruction as a means of teaching the English speech act of refusal. Hamouda divided the forty four participants into two groups. Both 'control' and 'treatment', according to terms used by Hamouda, comprised 22 participants. Participants were freshmen majoring in English language, enrolled at the Department of English, Qassim University, Saudi Arabia. All of them study English as a foreign language, and none of them stayed or been to a country where English is the mother tongue. They were taught a number of refusal-based-English conversations adopted in the English book "Headway". Hamouda collected data through two written instruments; written DCT and a 'self report'. The written DCT contained 12 situations equally divided to cover suggestion, invitation and request with four situations each. All the 12 situations observed various kinds of social relations between the interlocutors. Participants were asked as well to write a 'self report' in order to ascertain the results of the DCT on the one hand and make an evaluation of the impact of explicit pragmatic instruction on developing the Saudi EFL learners' pragmatic performance. Hamouda reported that the development of Saudi EFL learners' pragmatic competence is attributed to the use of explicit pragmatic instruction. Saudi EFL learners have positive perception towards the teaching of pragmatics.

Bardovi-Harlig (2010) raised, for instance, some of these factors which are mostly related to pragmatic teaching process including the devised pragmatic input, L2 pragmatic instructions and other two important factors which are more related to ESL learners' exposure to L2 pragmatics and their L1 transfer into their L2 pragmatic output. In this regard, Barron (2003) argued that it is the position of English in a nonnative speaking country which helps create the environment for better L2 
pragmatic development. For example, in countries were English is used as a second language, on the contrary to those where English is used as a foreign language, L2 learners are more eligible to have L2 pragmatic input than the EFL learners because they have opportunities of language practice outside the classroom borders either with their native speakers teachers or even with other native speakers who exist in such countries like Singapore, Malaysia and India. On the other hand, Schauer (2004) found that staying in a L2-speaking environment gives some EFL learner a privilege to develop their L2 pragmatic competence over those EFL learners who have never been to any of the English native speaking countries.

Niezgoda and Rover (2001) pointed out that studying English in the mother-tongue environment does not enrich EFL learners' knowledge in pragmatics as much as it enriches their knowledge in English grammar. Learning English in a foreign language context does provide EFL learners with opportunities of intercultural communication and does not develop their L2 pragmatic competence due to the lack of proper pragmatic input. In a similar finding, Kasper and Rose (2002) indicated that having contacts with English native speakers does not often guarantee the provision of L2 pragmatic input. Meanwhile Taguchi (2008) diminished the importance of the environment role in enhancing the learners' L2 pragmatics which can be successfully developed over time within the first language learning context. As such Taguchi claimed that staying in native-speaking countries is not a prerequisite for L2 pragmatic development.

Other interlanguage pragmatic studies handled the role of L2 pragmatic instruction in developing the pragmatic competence of ESL learners (e.g. Takimoto, 2008; \& Bardovi-Harlig, 2013). These studies are based on the concept of potential teaching of pragmatic competence. In other words, ESL learners can be taught L2 pragmatics. In this regard, Rose (2005) clarified that even though pragmatic development may happen without L2 pragmatic instruction, but it consumes longer period of time than in the case of using L2 pragmatic instruction. Furthermore, EFL learners who received L2 pragmatic instruction perform better than those learners who did not. Tateyama (2001) and Takahashi (2005) found that using explicit L2 pragmatic instruction is more effective in developing ESL learners' pragmatic competence. On the other hand, Cook (2001) asserted that it the implicit L2 pragmatic instruction and not the explicit one which can highly develop the ESL learners' pragmatic competence. However, Soler (2005) and Koike and Pearson (2005) emphasized that the combination of both explicit and implicit types L2 pragmatic instruction is useful for the development of ESL learners' 
pragmatic competence. This helps develop ESL learners' awareness of L2 pragmatic norms and strategies; their use of discourse markers; and improve their metapragmatic knowledge.

\section{Conceptual framework}

The conceptual framework of the present study is based on two of the four variables affecting the development of L2 pragmatic competence as devised by Bardovi-Harlig (2013). These four variables are L1 culture including social distance and social power, L2 linguistic competence, environment, and L2 instructions. The present study focuses only on L1 culture and L2 instruction. In addition, the present study adopts the classification of refusal and acceptance strategies, which is summarized in Table 1, as devised by Salazar, Safont, and Codina (2009).

\section{Methodology}

\section{Participants}

Thirty Egyptian EFL tertiary students participated in the study. They were divided into two groups with fifteen students each. Group A comprised English language major students who are enrolled at the Department of Languages and Translation whereas group B included ESP students enrolled at the Department of Tourism.

\section{Data collection}

\section{Instrument}

The discourse completion task (DCT) consists of 12 situations which are adopted and adapted from several ILP studies like Barron (2003), Honglin (2007), Schneider and Barron (2008), and Linde (2009) (Table 1). Another Arabic-translated version of the DCT was used as well to ensure group B participants' full understanding of the instructions and the included situations of invitation. Situations are designed according to the contextual variables of social distance and social status. Social distance (D) is of binary value; it means to what extent both interlocutors know each other. When the interlocutors know each other, the social distance is symbolized as (-D). However, the symbol (+D) indicates that the interlocutors do not know each other. Out of the 12 situations, six situations indicated that the interlocutors are familiar to each other or know each other (- D). On the other hand, six situations indicated that the interlocutors do not know each other $(+\mathrm{D})$. According to Schneider and Barron (2008), social power is of two types: symmetrical or asymmetrical. In other words, the interlocutors are either equal or unequal in their social status. The inviter (speaker) symbolized as (S) can have higher social status than the invitee (hearer) symbolized as $(\mathrm{H})$. This social status is expressed as $\mathrm{S}>\mathrm{H}$. When the invitee is higher in his/her social status than the inviter, it is expressed as $\mathrm{S}<\mathrm{H}$. When both the inviter and the invitee have the same social status, it is expressed as $\mathrm{S}=$ 
$\mathrm{H}$. The 12 situations equally indicated the different categories of the social status. That is, four situations for each of $\mathrm{S}<\mathrm{H}, \quad \mathrm{S}>\mathrm{H}$, and $\mathrm{S}=\mathrm{H}$.

Table 1: Contextual variables of the DCT situations

\begin{tabular}{|c|c|c|c|}
\hline Situations & $\begin{array}{c}\text { Type of } \\
\text { Response }\end{array}$ & Social Distance & Social Status \\
\hline $\begin{array}{l}\text { 1. Your boss } \\
\text { stops you and } \\
\text { invites you to go } \\
\text { to his house } \\
\text { warming party. }\end{array}$ & $\begin{array}{l}\text { You decline his } \\
\text { invitation. }\end{array}$ & $-\mathrm{D}$ & $\mathrm{S}>\mathrm{H}$ \\
\hline $\begin{array}{l}\text { 2. Your friend } \\
\text { invites you to go } \\
\text { to the beach. }\end{array}$ & You cannot go. & $-\mathrm{D}$ & $\mathrm{S}=\mathrm{H}$ \\
\hline $\begin{array}{l}\text { 3. A student } \\
\text { invites the senior } \\
\text { lecturer to go to } \\
\text { a party. }\end{array}$ & Refusal & $-\mathrm{D}$ & $\mathrm{S}<\mathrm{H}$ \\
\hline $\begin{array}{l}\text { 4. A salesman } \\
\text { invites the } \\
\text { chairman of a } \\
\text { company to one } \\
\text { the expensive } \\
\text { restaurants. }\end{array}$ & Acceptance & $+\mathrm{D}$ & $\mathrm{S}<\mathrm{H}$ \\
\hline $\begin{array}{l}\text { 5. A student } \\
\text { invites his/her } \\
\text { dean to attend } \\
\text { his/her Ph.D. } \\
\text { thesis defense }\end{array}$ & Acceptance & $-\mathrm{D}$ & $\mathrm{S}<\mathrm{H}$ \\
\hline $\begin{array}{l}\text { 6. A student } \\
\text { invites his/her } \\
\text { newly appointed } \\
\text { teacher to a } \\
\text { picnic }\end{array}$ & Refusal & $+\mathrm{D}$ & $\mathrm{S}<\mathrm{H}$ \\
\hline $\begin{array}{l}\text { 7. A professor } \\
\text { invites the }\end{array}$ & Acceptance & $+\mathrm{D}$ & $\mathrm{S}>\mathrm{H}$ \\
\hline
\end{tabular}




\begin{tabular}{|c|c|c|c|}
\hline \multicolumn{4}{|c|}{ Dr. Marghany Mahmoud Marghany } \\
\hline Situations & $\begin{array}{l}\text { Type of } \\
\text { Response }\end{array}$ & Social Distance & Social Status \\
\hline $\begin{array}{c}\text { university } \\
\text { teacher to } \\
\text { attend a seminar }\end{array}$ & & & \\
\hline $\begin{array}{l}\text { 8. Your friend } \\
\text { invites you to } \\
\text { dinner as you } \\
\text { will travel } \\
\text { tomorrow for } \\
\text { another state. }\end{array}$ & $\begin{array}{c}\text { You accept the } \\
\text { invitation }\end{array}$ & $-\mathrm{D}$ & $\mathrm{S}=\mathrm{H}$ \\
\hline $\begin{array}{l}\text { 9. A neighbor's } \\
\text { invitation }\end{array}$ & Refusal & $+\mathrm{D}$ & $\mathrm{S}=\mathrm{H}$ \\
\hline $\begin{array}{l}10 . \quad \text { Your } \\
\text { supervisor } \\
\text { invites you for } \\
\text { lunch }\end{array}$ & Acceptance & $-\mathrm{D}$ & $\mathrm{S}>\mathrm{H}$ \\
\hline $\begin{array}{l}\text { 11. Your newly } \\
\text { appointed boss } \\
\text { on his first day } \\
\text { in office invites } \\
\text { you to a } \\
\text { barbeque party. }\end{array}$ & Refusal & $+\mathrm{D}$ & $\mathrm{S}>\mathrm{H}$ \\
\hline $\begin{array}{lr}12 . \quad \text { A } & \text { newly } \\
\text { appointed } & \text { staff } \\
\text { at your company } \\
\text { invites } & \text { for } \\
\text { dinner. } & \end{array}$ & Acceptance & $+\mathrm{D}$ & $\mathrm{S}=\mathrm{H}$ \\
\hline
\end{tabular}




\section{Procedures of data collection}

Data were collected in two sessions, each session lasted for an hour (60 minutes) allocated for the DCT. Data were collected from each group of participants in a separate session. That is, a session for data collection from group A participants; and another session for data collection from group B participants. In all sessions, participants were briefed on the DCT questionnaire as they were orally informed about its instructions.

\section{Pilot study}

The DCT was piloted using 10 Egyptian EFL students. The purpose was to determine its reliability and the easiness or difficulty of its items. The pilot study results indicated that the Cronbach Alpha coefficient of the DCT is .96 suggesting high reliability of its items. As the pilot study participants complained of the DCT length, the DCT items were reduced from 18 to 12 items.

\section{Data analysis}

The study relied on descriptive statistics where the frequencies, mean scores and percentages of the categories of refusal and acceptance strategies were computed. In addition, the study conducted one way analysis of variance (ANOVA) to measure the statistical significance between the categories of contextual variables (social distance and social power) and the participants' refusal and acceptance strategies either within or among the groups of participants.

\section{Findings}

As to the first question: How do Egyptian EFL tertiary students vary in their refusal and acceptance of invitation according to their field of study?

Frequency, percentage and mean score of the acceptance and refusal strategies used by the two groups of participants are indicated in Table 2. Acknowledgement was found to be the highest acceptance strategy adopted by group A (83\%) and group B (100\%). Although English-major Egyptian EFL participants in group A and those ESP Egyptian students showed relative similarity in using acknowledgement and gratitude, they largely differed in using positive opinion $(50 \%$ for group A while it was not used at all by group B) and well-wishing (25\% for group A and 2\% for group B). English-major Egyptian EFL participants largely differed from ESP students in adopting the acceptance strategy of well-wishing (25\% for the former and $16.6 \%$ for the latter). Whereas English-major Egyptian EFL students used positive opinion strategy to indicate their acceptance (50\%), ESP Egyptian participants were unaware of such strategy as they did not use at all.

As to refusal strategies, participants of the two groups were generally similar in giving reasons for refusing invitation; explanation 


\section{Dr. Marghany Mahmoud Marghany}

was the highest refusal strategy among all participants. However, English-major Egyptian EFL students were distinguished from their counterparts in using joke as a refusal strategy (8.3\%). Participants in groups $\mathrm{A}$ and $\mathrm{B}$ were similar in adopting regret and direct negative ability as the second and third highest refusal strategies. This finding is compatible with those reported by Al-Issa (2003), but contradicts those reported by Hamoud (2014). It was remarkable that none of the Egyptian EFL participants in the two groups could use strategies like pause fillers, promise for future acceptance, well-wishing and positive opinion when expressing refusal of the invitation. This finding posed a question on the necessity of training Egyptian EFL learners on using refusal strategies adopted by native speakers.

L1 transfer was evident in the responses of Egyptian EFL participants in both groups A and B. For examples, they used Arabic words like "inshallah" (God willing), "waallah" (by God), "Allah yabrik feek"; a well-wishing sentence in Arabic which means "May Allah bless you". This finding pays the attention of FL instructors to teach Egyptian EFL learners how to abandon the use of some Arabic idioms while expressing their refusal or acceptance. This finding is similar to those reported by Wang (2003), Al-Eryani (2007) and Rakowicz (2009).

Table 2: Frequencies, percentages and mean Scores of refusal and acceptance responses by participants in the two groups

\begin{tabular}{|c|c|c|c|c|c|c|c|c|}
\hline Group & Acceptance & $\mathrm{F}$ & $\%$ & $\mathrm{M}$ & Refusal & $\mathrm{F}$ & $\%$ & $\mathrm{M}$ \\
\hline \multirow[t]{10}{*}{ G A } & Indirect & & & & Direct & & & \\
\hline & Acknowledgement & 10 & 83 & $\mathbf{3 . 3}$ & Negative ability & 8 & 66.6 & 2.6 \\
\hline & Checking & 1 & 8.3 & 0.3 & Indirect regret & 9 & 75 & 3 \\
\hline & Gratitude & 6 & 50 & 2 & Wish & 2 & 16.6 & 0.6 \\
\hline & Idiom & 2 & 16.6 & 0.6 & Explanation & 12 & 100 & 4 \\
\hline & Offer & 3 & 25 & 1 & Promise future & 1 & 8.3 & 0.3 \\
\hline & Solidarity & 1 & 8.3 & 0.3 & Gratitude & 4 & 33.3 & 1.3 \\
\hline & Positive opinion & 6 & 50 & 2 & Well- Wishing & $\mathbf{1}$ & 8.3 & 0.3 \\
\hline & Suggestion & $\mathbf{1}$ & 8.3 & 0.3 & Joke & $\mathbf{1}$ & 8.3 & 0.3 \\
\hline & Well Wishing & 3 & 25 & 1 & & & & \\
\hline \multirow{8}{*}{ G B } & Direct & 1 & 8.3 & 0.3 & Direct & & & \\
\hline & Indirect & & & & Negative ability & 4 & 33.3 & 1.3 \\
\hline & Acknowledgement & 12 & 100 & & Indirect regret & 5 & 41.6 & 1.6 \\
\hline & Checking & 2 & 16.6 & 0.6 & Explanation & 12 & 100 & 4 \\
\hline & Gratitude & 4 & 33.3 & 1.3 & Promise future & 1 & 8.3 & 0.3 \\
\hline & Solidarity & 1 & 8.3 & 0.3 & Positive opinion & 1 & 8.3 & 0.8 \\
\hline & Well-wishing & 2 & 16.6 & 0.6 & Gratitude & 1 & 8.3 & 0.8 \\
\hline & & & & & Well-wishing & 1 & 8.3 & 0.8 \\
\hline
\end{tabular}


As to the second and third questions: Do their refusal and acceptance of invitation vary in terms of the social distance? And how do refusal and acceptance of invitation vary among Egyptian EFL tertiary students according to different levels of social power?

One way analysis of variance (ANOVA) was conducted in order to determine the statistically significant influence which each of the contextual variables may have on the number of refusal strategies among the two groups. Tables 3, 4, 5, 6, 7 and 8 showed that the contextual variables have statistically significant influences on the use of refusal strategies within each group and among the two groups of participants at the 0.05 level. This finding asserted the importance of teaching the underlying cultural components of pragmatic behavior adopted by the English native speakers to Egyptian EFL learners. This finding is similar to those reported by Al-Khatib (2006) and Al-Eryani (2007).

Table 3: ANOVA on the influence of $S<H(D+)$ on refusal responses among the two groups

\begin{tabular}{|l|r|r|r|r|r|}
\hline & Sum of Squares & \multicolumn{1}{|c|}{ df } & Mean Square & F & Sig. \\
\hline Between Groups & 259.247 & 3 & 86.416 & 206.646 & .000 \\
Within Groups & 4.182 & 10 & .418 & & \\
Total & 263.429 & 13 & & & \\
\hline
\end{tabular}

Table 4: ANOVA on the influence of $S<H$ (D-) on refusal responses among the two groups

\begin{tabular}{|l|r|r|r|r|r|}
\hline & Sum of Squares & \multicolumn{1}{|c|}{ df } & Mean Square & F & Sig. \\
\hline Between Groups & 241.862 & 2 & 120.931 & 61.680 & .000 \\
Within Groups & 21.567 & 11 & 1.961 & & \\
Total & 263.429 & 13 & & & \\
\hline
\end{tabular}

Table 5: ANOVA on the influence of $S=H(D+)$ on refusal responses among the two groups

\begin{tabular}{|l|r|r|r|c|r|}
\hline & Sum of Squares & df & Mean Square & F & Sig. \\
\hline Between Groups & 172.519 & 2 & 86.260 & 10.437 & .003 \\
Within Groups & 90.909 & 11 & 8.264 & & \\
Total & 263.429 & 13 & & & \\
\hline
\end{tabular}

Table 6: ANOVA on the influence of $S=H(D-)$ on refusal responses among the two groups

\begin{tabular}{|l|r|r|r|r|r|}
\hline & Sum of Squares & df & Mean Square & F & Sig. \\
\hline Between Groups & 173.829 & 2 & 86.914 & 10.670 & .003 \\
Within Groups & 89.600 & 11 & 8.145 & & \\
Total & 263.429 & 13 & & & \\
\hline
\end{tabular}


Dr. Marghany Mahmoud Marghany

Table 7: ANOVA on the influence of $\mathrm{S}>\mathrm{H}(\mathrm{D}+)$ on refusal responses among the two groups

\begin{tabular}{|l|r|r|r|r|r|}
\hline & Sum of Squares & \multicolumn{1}{|c|}{ df } & Mean Square & F & Sig. \\
\hline Between Groups & 258.747 & 2 & 129.373 & 303.965 & .000 \\
Within Groups & 4.682 & 11 & .426 & & \\
Total & 263.429 & 13 & & & \\
\hline
\end{tabular}

Table 8: ANOVA on the influence of $S>H$ (D-) on refusal responses among the two groups

\begin{tabular}{|l|r|r|r|r|r|}
\hline & Sum of Squares & \multicolumn{1}{|c|}{ df } & Mean Square & F & Sig. \\
\hline Between Groups & 233.862 & 2 & 116.931 & 43.503 & .000 \\
Within Groups & 29.567 & 11 & 2.688 & & \\
Total & 263.429 & 13 & & & \\
\hline
\end{tabular}

\section{Implications for the EFL teaching process}

As to the fourth question: What are the teaching implications that can be drawn for improving foreign language teaching?

Undoubtedly, FL instructors at the Higher Institute for Specific studies should be aware of the meaning of pragmatics, so that they can develop pedagogically oriented activities addressing the needs for developing the pragmatic competence of their students. This development should be based on what pragmatic aspects should be taught and the reasons behind teaching pragmatics. In this regard, Celce-Murcia (2007) explained that FL instructors should develop the awareness among their students of the fundamental cultural variables of a certain communicative action which in turn affects their choices of certain linguistic formulas. Not only are these cultural variables restricted to age, gender or social class affiliation, but also comprise norms, values and beliefs adopted by the target language community. Therefore, Egyptian EFL learners should be taught and exposed to the exactly same linguistic choices adopted by the target language community. This can be done through teaching conversation either at the Department of Languages and Translation where conversation is one of the core courses or at the Department of Tourism where English is taught as an ESP course. Similarly, the underlying cultural values of a communicative action can also be taught to Egyptian EFL students.

This can be done based on exposing them to the cultural facts of the target language community. For examples, native speakers' indirect strategies of refusal like 'promise future', 'positive opinion' or 'hedging' and their acceptance strategies like 'checking', 'solidarity', or 'wellwishing' should be taught to Egyptian EFL students. This can be done through various listening and speaking activities related to refusing and/or accepting invitation. In this case, Brown (2007) and Sanz and Leow 
(2011) pointed out that FL instructors should not explicitly make Egyptian EFL learners aware of learning pragmatic competence. This approach is consistent with CLT which is theoretically based on internalized knowledge rather than on teaching language forms explicitly. This approach also enhances the fluency of Egyptian EFL learners as it is an essential component of FL teaching.

According to Hofstede, Hofstede and Minkov (2010), FL instructors may face a challenge in teaching the target language community culture due to the homogeneity nature of culture to which all native speakers adhere to. Culture as such can be divided based on the principles of individualism and collectivism or high and low social distance. Thus, Egyptian EFL learners should be taught that English native speakers usually adopt formal indirect and more elaborated strategies for communication. They could be also taught to abandon the use of some Arabic idioms while expressing their refusal or acceptance like 'Allah yabrik feek ' (May Allah bless you) or 'Inshalla' (God willing). As such, FL instructors are required to develop culturally-based materials for teaching the pragmatic behaviour of English native speakers.

\section{Conclusion}

Although English-major Egyptian EFL participants in group A and those ESP Egyptian students showed relative similarity in using acknowledgement and gratitude, they largely differed in using positive opinion. English-major Egyptian EFL participants largely differed from ESP students in adopting the acceptance strategy of well-wishing. On the contrary to English-major Egyptian EFL students, ESP Egyptian participants were unaware of using the positive opinion strategy when expressing acceptance of invitations. Both English-major Egyptian EFL students and ESP Egyptian students adopted similar strategies of refusal and gave reasons for refusing invitations. The study proved that Egyptian EFL students were in a need for learning the refusal strategies adopted by English native speakers.

The present study emphasized how important to teach pragmatic behavior of the English native speakers to Egyptian EFL learners. Teaching pragmatics should not be done in an explicit way, but it should be rather based on internalized knowledge. Egyptian EFL learners should be taught the indirect, formal and more elaborated strategies which English native speakers usually adopt in their communication. They should be also taught to abandon the use of some Arabic idioms while expressing refusal or acceptance of invitations.

\section{Suggestions for further research}

Below are some suggestions for further research: 


\section{Dr. Marghany Mahmoud Marghany}

1. A study can be conducted to investigate the other two contextual variables which the present study did not investigate, namely environment and L2 linguistic competence.

2. The present study can be replicated using other speech acts like requesting, complaining, complimenting, greeting etc.

3. The sociolinguistic and sociocultural variables affecting the communicative behavior of English native speakers can be investigated as well.

4. Another study may discuss how FL instructors can devise target language community culturally-based activities for teaching pragmatics.

5. It is also appropriate to investigate the FL instructors' awareness of cultural values, norms and beliefs adopted in the target community.

6. It is useful as well to analyze the Egyptian EFL learners' pragmatic output in line with Brown and Levinson's (1987) politeness theory.

7. An investigation of the positive and negative Arabic transfer into the linguistic formulas of Egyptian EFL learners' pragmatic output can be conducted. 


\section{References}

Al-Eryani, A. (2007). Refusal strategies by Yemeni EFL learners. The Asian EFLJournal 9(2):19-31.

Al-Issa, A. (2003). Sociocultural transfer in L2 speech behaviors: Evidence andmotivating factors. International Journal of Intercultural Relations, 27, 581-601.

Al-Khatib, M. A. (2006). The pragmatics of invitation making and acceptance in Jordan society. Journal of Language and Linguistics 5(2), 272-294.

Bardovi-Harlig, K. (2006). Interlanguage development: Main routes and individual paths. AILA Review, 19, 69-82.

Bardovi-Harlig, K. (2010). Pragmatics and second language acquisition. In R. Kaplan (Ed.,) The handbook of applied linguistics, (2 $2^{\text {nd }}$ ed 232-243). Oxford, UK: Oxford University Press.

Bardovi-Harlig, K. (2013). Developing L2 pragmatics. Language Learning, 63, (1), 68-86.

Barron, A. (2003). Acquisition in interlanguage pragmatics: Learning how to do things with words in a study abroad context. Amsterdam/Philadelphia: John Benjamines.

Brown, H. D. (2007). Teaching by principles: An interactive approach to language pedagogy (3rd ed.). White Plains, NY: Pearson Education.

Celce-Murcia, M. (2007). Rethinking the role of communicative competence in language teaching. In E. Alcón Soler and M. P. Safont Jorda (Eds.), Intercultural language use and language learning (pp. 4157). Dordrecht, Netherlands: Springer.

Cook, H. M. (2001). Why can't learners of JFL distinguish polite from impolite speech style, In K.R Rose and G. Kasper (eds.). Pragmatics in Language Teaching. New York: Cambridge University Press, 125-144.

Felix-Brasdefer, J.C. (2003). Declining an invition: A cross-cultural study of pragmatic strategies in American English and Laain American Spanish. Multilingua, 22, 225-255.

Hamouda, A. (2014). The effect of explicit instruction on developing Saudi EFL learners' pragmatic competence in refusal formulas. Research Journal of English Language and Literature (RJELAL), 2, (1), 138-160. Hofstede, G., Hofstede, G. J., \& Minkov, M. (2010). Cultures and organizations: Software of the mind: Intercultural cooperation and its importance for survival. New York, NY: McGraw-Hill. 


\section{Dr. Marghany Mahmoud Marghany}

Honglin, L. (2007). A Comparative Study of Refusal Speech Acts in Chinese and American English. Canadian Social Science, 3 (4) available online at:

http://escanada.net/index.php/css/article/download/j.css.19236697200703 $\underline{04.014 / 440}$

Kasper, G. (2000). Pragmatics in language teaching: Why and how it should be taught. Osaka: Kansai University.

Kasper, G., and Rose, K. R. (2001). Pragmatics in Language Teaching. Cambridge: Cambridge University Press.

Kasper, G. and Rose, K. (2002). Pragmatic development in a second language. Malden, MA: Wiley Blackwell.

Koike, D. A., and Pearson, Lynn, (2005). The effect of instruction and feedback in the development of pragmatic competence. System, 33: 481501.

Linde, Á. (2009). How polite can you get? A comparative analysis of interlanguage pragmatic knowledge in Spanish and Moroccan EFL university students. PortaLinguarum: Revistainternacional de didáctica de laslenguasextranjeras, 12, 133-148.

Niezgoda, K. and Roever, C. (2001). Pragmatic and grammatical awareness: A function of the learning environment, In K.R. Rose and G. Kasper (eds.). Pragmatics in Language Teaching. Cambridge: Cambridge University Press, 63-79.

Rakowicz, A. (2009). Ambiguous invitations: The interlanguage pragmatics of Polish English language learners. New York: VDM Publishing House.

Rose, K. R. (2005). On the effects of instruction in second language pragmatics. System, 33: 385-399.

Salazar-Campillo, P., Safont-Jordà, M. P. and Codina-Espurz, V. (2009).

Refusal strategies: A proposal from a sociopragmatic approach. RaL:

Revista Electrónica de Lingüística Aplicada, 8, 139-150.

Salmani-Nodoushan, M. A. (2006). A comparative socio-pragmatic study on ostensible invitations in English and Farsi. Speech Community, 48, 8, 903-912.

Sanz, C. and Leow, R. P. (Eds.). (2011). Implicit and explicit language learning: Conditions, processes, and knowledge in SLA and bilingualism. Washington, DC: Georgetown University Press. 
Schauer, G. A. (2004). May you speak louder maybe? Interlanguage pragmatic development in requests. EUROSLA Yearbook 4: 253-272. Schneider, K and Barron, A. (Eds.) (2008). Variational Pragmatics: A Focus on Regional Varieties in Pluricentric Languages. Amsterdam/Philadelphia: John Benjamins.

Soler, E. A. (2005). Does instruction work for learning pragmatics in the EFL context? System, 33, 417-435.

Suzuki, T. (2009). How can American university students "invite" others? A corpus based study of linguistic strategies for the speech act of invitations. A paper presented at the $11^{\text {th }}$ Annual Conference of Pragmatics Society of Japan, held at Matsuyama University (Matsuyama, Ehime), 20 th DEC., 2008.

Taghuchi, N. (2008). Pragmatic competence. New York: Mouton de Gruyter.

Takimoto, M. (2008). The effects of deductive and inductive instruction on the development of language learners' pragmatic competence. The Modern LanguageJournal, 92(3), 369-386.

Takahashi, S. (2005). Pragmalinguistic awareness: Is it related to motivation andproficiency? Applied Linguistics, 26(1): 90-120.

Tateyama, Y. (2001). Explicit and implicit teaching of pragmatic routine:Japanese sumimasen, In K.R Rose and G. Kasper (eds.). Pragmatics in Language Teaching. New York: Cambridge University Press, 125-144.

Wang, Y. (2003). Refusal strategies in American and Chinese cultures: A comparative study, Retrieved on July 14, 2015 from http://deal.ohiostat.edu 